\title{
Treatment of wastewater from service areas at motorways
}

\author{
Małgorzata Makowska*, Jakub Mazurkiewicz \\ Poznań University of Life Sciences, Poland \\ Department of Hydraulic and Sanitary Engineering \\ *Corresponding author's e-mail: mmak@up.poznan.pl
}

\begin{abstract}
Keywords: motorway service areas, local treatment plants, biofilters, wastewater treatment, facilities at transport routes.

Abstract: This paper deals with wastewater treatment systems placed in motorway service areas (MSAs). In the years 2008-2009 eight of such facilities installed on the stretch of the A2 motorway between Poznań and Nowy Tomyśl were examined and analyzed. The system consists of a septic tank, a submerged aerated biofilter and an outflow filter. The volume of traffic on the highway was analyzed, the amount of water use was measured and peak factors were calculated. On this basis it was concluded that the inflows to the wastewater treatment systems in many cases exceeded the nominal design values.

Based on the analysis of effluent quality it was found that the effects of plant operation in large part did not meet the requirements. It was found that the bioreactor aeration system and the design of the suspension separator (outflow filter) should be modified. One of the solutions was to use the soil-reed bed for wastewater treatment. The treatment of wastewater from the MSAs is a task that must take into account the unusual character of these facilities and the atypical quality of the effluent.
\end{abstract}

\section{Introduction}

Since the second half of the 20th century in highly developed countries the length of highways has increased significantly, mostly to accommodate public transportation. This created increased requirements for the equipment of road infrastructure in motorway service areas (MSAs), where sanitary facilities, catering, restaurants, rest areas, car washes, petrol stations, viewpoints, etc. are localized. Also in Poland in recent years highways have become a new and important part of transportation networks. The length of motorways in Poland is much lower than in other European Union countries. In 2008 per $1,000 \mathrm{~km}^{2}$ there were $2.4 \mathrm{~km}$ motorways, whereas in Slovakia it was 7.8, in the Czech Republic 8.8, in France 20.1 and, in Italy 22, not to mention Germany with its $35.4 \mathrm{~km}$ (Expertise 2010) and over 40,000 different MSAs.

Because MSAs are located mainly in rural areas, often away from the municipal infrastructure, an important problem is connected with the supply of these facilities with tap water and wastewater disposal. In many cases it is not possible to discharge wastewater to the central wastewater treatment plant and therefore an individual solution to the problem on site is required. It is necessary to build and operate a cesspool or an on-site wastewater treatment plant. The system design must take into account the relatively high variability both in the amount of wastewater determined by traffic intensity and in composition of wastewater, which differs from a typical domestic one. In developed countries on-site plants used for such facilities are becoming more and more technologically advanced; many of them produce the treated wastewater suitable for flushing toilets or washing of trucks (Jowett et al. 2008, Parker et al. 1977). This reduces both water consumption and the environmental impact of pollutants. Leverenz and Tchobanoglous (2007) recently conducted a study on various types of wastewater treatment technologies addressed to motorway service areas, including the re-use of treated sewage. Based on the results of a 15-year period they performed optimization calculations and formulated recommendations for the selection of such systems providing adequate performance at minimum costs.

The amount of wastewater generated in MSAs depends primarily on the facilities at a given location and on vehicle traffic intensity. Seabloom and Sylvester (1972) estimated for U.S. highways in the 1970s that one user of sanitary appliances needs on average 13.3 liters of waters. According to those authors the average of 30 persons used one appliance per hour, with one person using maximum $12 \%$ daily water consumption of a given device. Londong and Meyer (2010), on the basis of detailed research on German motorways, found that the amount of water used ranges from 4 to $8 \mathrm{dm}^{3}$ per user.

The quality of wastewater from facilities at transport routes may vary greatly from the quality of typical domestic wastewater, due to the highly loaded mixtures of fats, urea and cellulose. A characteristic feature of these wastewaters, comparing to typical municipal wastewater, is a much lower ratio of organic to nitrogen compounds, within the range of $0.5 \leq \mathrm{C} / \mathrm{N} \geq 3.0$. Table 1 contains data relating to effluent quality from Polish, American, Canadian and German sources (Jowett et al. 2008, Seabloom and Sylvester 1972, Londong and Meyer 2010, Helman-Grubba et al. 2004). 
Due to the unusual characteristics of wastewater from MSAs it is important to estimate their design values focusing on their high hourly and daily variations, as well as weekly and seasonal ones. An onsite wastewater treatment plant may include septic tanks, soil absorption systems, reactors with activated sludge or attached biomass and constructed wetland systems, and when necessary, grease or oil separators as pretreatment facilities.

In any case it is necessary to provide a wastewater retention or proper recirculation system, to minimize the negative impact of variations in wastewater flow. The least preferred option is to store the wastewater in cesspools. In such cases the separation of toilets and dry urinals may significantly reduce the stored and transported water volume. One of the cheapest systems is a combination of a septic tank and a soil absorption system. In the United States in 1984 such systems were used at approximately $50 \%$ of MSAs. Wastewater from those facilities was classified as household wastewater, with the exception of locations where motor-homes emptied their sanitary tanks, for which the 30-day detention time in a septic tank (to ensure their dilution) was proposed (Pearson et al. 1984).

A recent large research performed in China on numerous on-site wastewater plants with activated sludge and membrane filters found their insufficient treatment efficiency, especially due to the improper selection of equipment and accessories (Song et al. 2011).

Londong and Meyer (2010) conducted a detailed study on small plants for MSAs in Germany. The most commonly used treatment systems were septic tanks combined with reactors (with activated sludge), submerged aerated biofilters, sand filters, constructed wetlands and wastewater ponds. The limit values for organic matter indicators in treated wastewater were exceeded by $5 \%$ for $\mathrm{BOD}_{5}$ and $14 \%$ for COD.

Interesting data may be found in a study of Kiss et al. (2011), where over a six-month period of monitoring and undertaken analyses showed that the raw wastewater concentration was very different from typical domestic wastewater. The researchers reported that the average $\mathrm{BOD}_{5}$, COD, TOC, TN and TP values were 880, 4900, 350, 238 and $8 \mathrm{mg} / \mathrm{L}$, respectively. Then evaluated systems were not working properly, due to design flaws and inappropriate control settings and maintenance. In order to improve the operation of wastewater treatment the researchers proposed and tested several modifications of the existing system. The most important changes included the aeration system and the RAS (return activated sludge) system. The former was adjusted to increase the oxygen concentration from about $0.5 \mathrm{mg} / \mathrm{dm}^{3}$ to $4 \mathrm{mg} / \mathrm{dm}^{3}$, which resulted in removal efficiency of COD, TOC and $\mathrm{TN}$ improved from $4 \%, 24 \%$ and a negligible level to $44 \%$, $61 \%$ and $19 \%$, respectively. In the second case the latter was changed by directing the RAS back to the aerobic chamber to increase in the MLSS concentration. The researchers reported that such wastewater treatment systems need to be designed for specific conditions and allow easy changes in control settings during service.

This paper presents the results of research concerning wastewater systems installed in motorway service areas located on the stretch between Poznań and Nowy Tomyśl. The systems consist of a septic tank, a submerged aerated biofilter and an outflow filter. The purposes of the study were to analyze the volume and quality of wastewater treated at those systems and to evaluate the operation of settlers and bioreactors. On the basis of the above-mentioned analyses technical solutions and recommendations for their proper maintenance and operation were proposed.

\section{Materials and methods}

Studies of on-site wastewater treatment plants installed at MSAs along the A2 motorway were performed from January 2008 to February 2009. In this study MSAs were described as HAS - Highway Service Area, HRA - Highway Rest Area and HTP - Highway Toll Point (Fig. 1). On-site inspections of all test sites, an inventory of sanitation facilities and comparisons of the actual situation with design documentation were firstly carried out. In order to evaluate treatment efficiency samples of primary treated wastewater (at the outlet of the primary settling tank) and secondary treated water (at the outflow of the

Table 1. Quality of raw wastewater from service areas at motorways by different sources

\begin{tabular}{|c|c|c|c|c|c|}
\hline Parameter & Unit & $\begin{array}{c}\text { Polish data* } \\
\text { (Helman-Grubba et al. } \\
\text { 2004) }\end{array}$ & $\begin{array}{c}\text { German data } \\
\text { (Londong and } \\
\text { Meyer 2010) }\end{array}$ & $\begin{array}{c}\text { American data } \\
\text { (Seabloom and } \\
\text { Sylvester 1972) }\end{array}$ & $\begin{array}{c}\text { Canadian data } \\
\text { (Jowett et al. 2008) }\end{array}$ \\
\hline $\mathrm{pH}$ & - & $7.4-8.6$ & - & $7.6-8.8$ & 7.6 \\
\hline $\mathrm{BOD}_{5}$ & $\mathrm{mg} \mathrm{O} / \mathrm{dm}^{3}$ & - & $266-665$ & $132-204$ & 300 \\
\hline $\mathrm{COD}_{\mathrm{Cr}}$ & $\mathrm{mg} \mathrm{O} / \mathrm{dm}^{3}$ & $103-217$ & $55-970$ & $355-478$ & - \\
\hline${\mathrm{N}-N H_{4}}_{\mathrm{N}-\mathrm{NO}_{3}}$ & $\mathrm{mg} \mathrm{N} / \mathrm{dm}^{3}$ & $70-266$ & - & - & - \\
\hline $\mathrm{N}-\mathrm{NO}_{2}$ & $\mathrm{mg} \mathrm{N} / \mathrm{dm}^{3}$ & $0.4-5.5$ & - & $0.38-0.73$ & - \\
\hline $\mathrm{N}_{\text {tot }}$ & $\mathrm{mg} \mathrm{N} / \mathrm{dm}^{3}$ & $0.005-1.15$ & $402-523$ & $98-201$ & - \\
\hline $\mathrm{P}_{\text {tot }}$ & $\mathrm{mg} \mathrm{P} / \mathrm{dm}^{3}$ & $3.34-5.43$ & $9.1-15,8$ & $23.6-41.5$ & - \\
\hline $\begin{array}{c}\text { Total suspended } \\
\text { solids, TSS }\end{array}$ & $\mathrm{mg} / \mathrm{dm}^{3}$ & $23.6-155.0$ & - & $138-196$ \\
\hline
\end{tabular}

\footnotetext{
* effluents from septic tanks
} 
biological section) were taken. During the study 12 sampling series were performed.

In the wastewater samples the following pollution indicators were determined: total suspended matter (direct gravimetric method PN-EN 872: $2007+\mathrm{Ap} 1$ : 2007), $\mathrm{pH}$ (potentiometric method, an Elmetron $\mathrm{pH}$-meter), organic compound contents expressed as $\mathrm{BOD}_{5}$ (by respiration, OxiTop WTW) and $\mathrm{COD}_{\mathrm{Cr}}$ (colorimetric method, Merck tests) and $\mathrm{N}_{\text {tot }}$ (colorimetric method, Merck tests). Simultaneously with the wastewater analyses sludge tests were carried out. The content of suspended biomass was determined, with the sedimentation test of activated sludge performed for 30 minutes in a 1-liter measuring cylinder and the sludge mass index calculated as well. During the study the monthly water use by the MSAs was reported and the average daily consumption was calculated in proportion to traffic intensity. Within 11 selected days water usage was daily recorded, and based on these daily readings the daily variability was identified. Afterwards, the loads of pollutants and the effectiveness of their removal were calculated. Also the maximum outflow from every facility and the daily volume of wastewater were calculated respectively in accordance with the standard PN-EN 12056-2 and according to the American recommendations. Technological calculations of selected wastewater treatment plants were verified. Data on vehicle traffic between Poznań and Nowy Tomyśl in 2008 were obtained from the operator headquarters (Autostrada Wielkopolska). Unfortunately, there were no data on the number of drivers and passengers in the vehicles.
The study deals with small wastewater treatment systems consisting of a septic tank (the mechanical part) and a submerged aerated biofilter (the biological part) assigned for treatment of wastewater from 20 or 40 PE. They were installed in the years 2002-2005 at highway rest areas, highway service areas and highway toll points along the A2 motorway, at an approx. 50 kilometer stretch between Poznań and Nowy Tomyśl (Fig. 1).

All the studied MSAs were equipped with car parks, public phones, toilets, tourist rest areas and playgrounds, and at some of them there were gas stations or restaurants, which had their own wastewater treatment systems, not tested by the authors (Tab. 2). Highways toll points were equipped with five lines in each direction, and one service lane.

The studied mechanical-biological treatment plants consisted of the following elements (Figs. 2 and 3):

- A dual-chamber septic tank with the active volume of $6.70 \mathrm{~m}^{3}$ (equipped with a T-pipe outlet, but without an outlet filter) - designed for the separation of suspended solids and excess sludge storage; the sludge was removed by a slurry tanker and transported to the site of further processing,

- A submerged aerated biofilter placed inside a cylindrical tank, the reactor was aerated through pipe diffusers installed at the tank bed,

- A clarification chamber, located downstream from the reactor, placed inside structured packaging (made of PVC), used for the separation of detached and

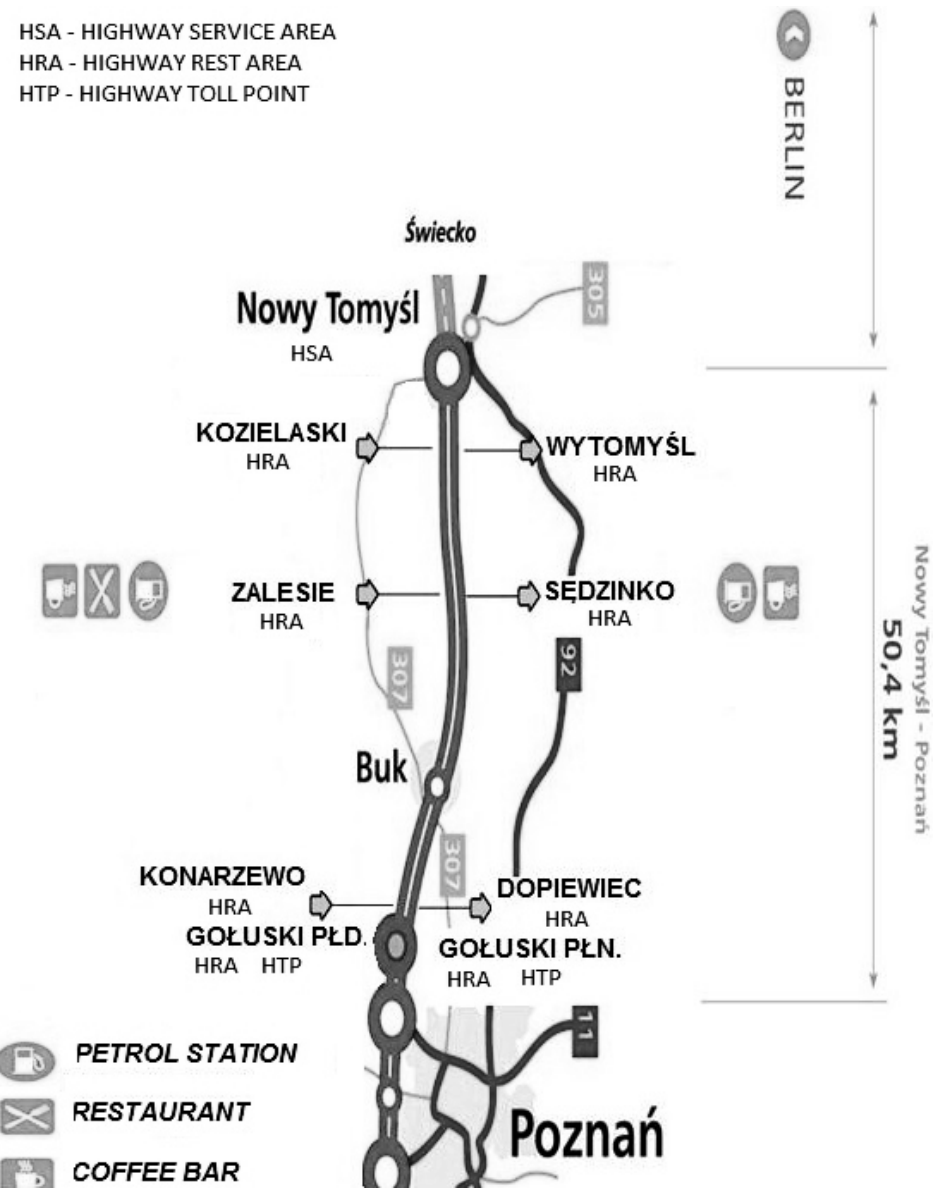

Fig. 1. The studied Poznań - Nowy Tomyśl stretch of motorway A2 
suspended biomass from the effluent; excess biomass was recirculated to the septic tank,

- A recirculation unit - an air-lift, facilitating the pumping of wastewater from the reactor to the septic tank,

- air-blowers for aeration of the submerged bed, periodically blowing the clarification chamber and supplying the air-lift,

- a control cabinet with a panel system controlling aeration, recirculation, washing of the clarification chamber and ventilation,
- hydraulic equipment allowing air flow in the wastewater treatment plant.

The treated wastewater was discharged directly to a receiver or to a buffer tank.

During the investigations the observations of traffic intensity on highway were performed. Wastewater volume was determined based on the consumption of water in each hour for one day. Chemical analyses of the quality of raw and purified sewage $\left(\mathrm{BOD}_{5}, \mathrm{COD}, \mathrm{TSS}\right)$ were performed by to the methods

Table 2. Characteristics of studied facilities along motorway A2; the Poznań - Nowy Tomyśl stretch

\begin{tabular}{|c|c|c|c|c|c|c|c|c|}
\hline \multirow{3}{*}{ No. } & \multirow{3}{*}{ Place } & \multirow{3}{*}{ Served objects } & \multicolumn{3}{|c|}{ Sanitary equipment in toilets, pieces } & \multicolumn{3}{|c|}{ WWTP capacity, $\mathrm{m}^{3} / \mathrm{d}$} \\
\hline & & & \multirow{2}{*}{ Wash-bowl } & \multirow{2}{*}{ WC } & \multirow{2}{*}{ urinal } & \multirow{2}{*}{ catalogue } & \multicolumn{2}{|c|}{ actual } \\
\hline & & & & & & & $Q_{\mathrm{dav}}$ & $Q_{d \max }$ \\
\hline 1 & Gołuski Płn. & Administrative objects & 8 & 9 & 2 & 8.0 & 2.0 & 3.9 \\
\hline 2 & Dopiewiec & Rest area & 5 & 10 & 2 & 8.0 & 3.5 & 6.5 \\
\hline 3 & Sędzinko & Rest area & 7 & 10 & 2 & 8.0 & 4.4 & 8.3 \\
\hline 4 & Wytomyśl & Rest area & 7 & 10 & 2 & 8.0 & 7.2 & 13.6 \\
\hline 5 & Kozielaski & Rest area & 7 & 8 & 2 & 8.0 & 8.6 & 16.3 \\
\hline 6 & Zalesie & Rest area & 7 & 8 & 2 & 8.0 & 5.9 & 11.1 \\
\hline 7 & Konarzewo & Rest area & 7 & 8 & 2 & 8.0 & 3.8 & 7.3 \\
\hline 8 & Gołuski Płd. & $\begin{array}{c}\text { Rest area }+ \\
\text { administrative objects }\end{array}$ & 2 & 7 & 2 & 4.0 & 2.0 & 3.8 \\
\hline
\end{tabular}

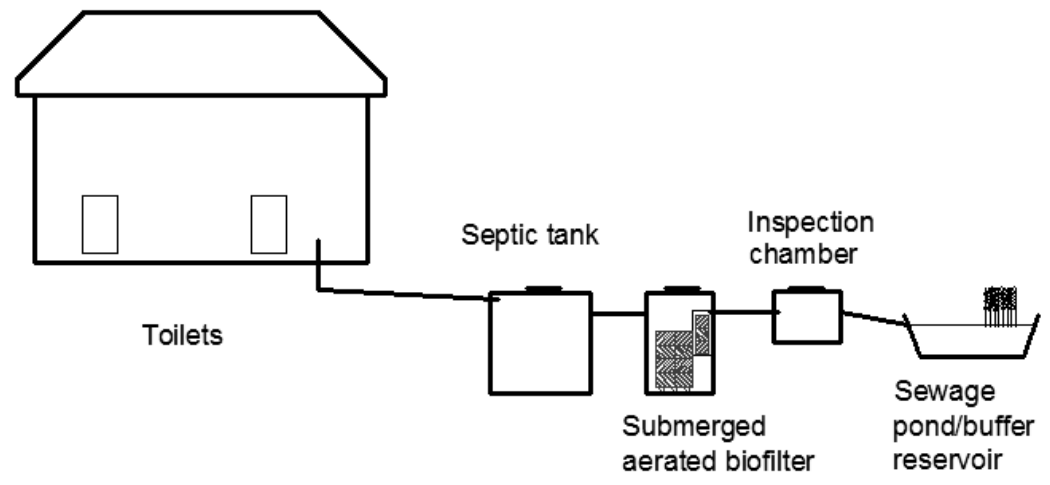

Fig. 2. A scheme of treatment systems at studied MSAs
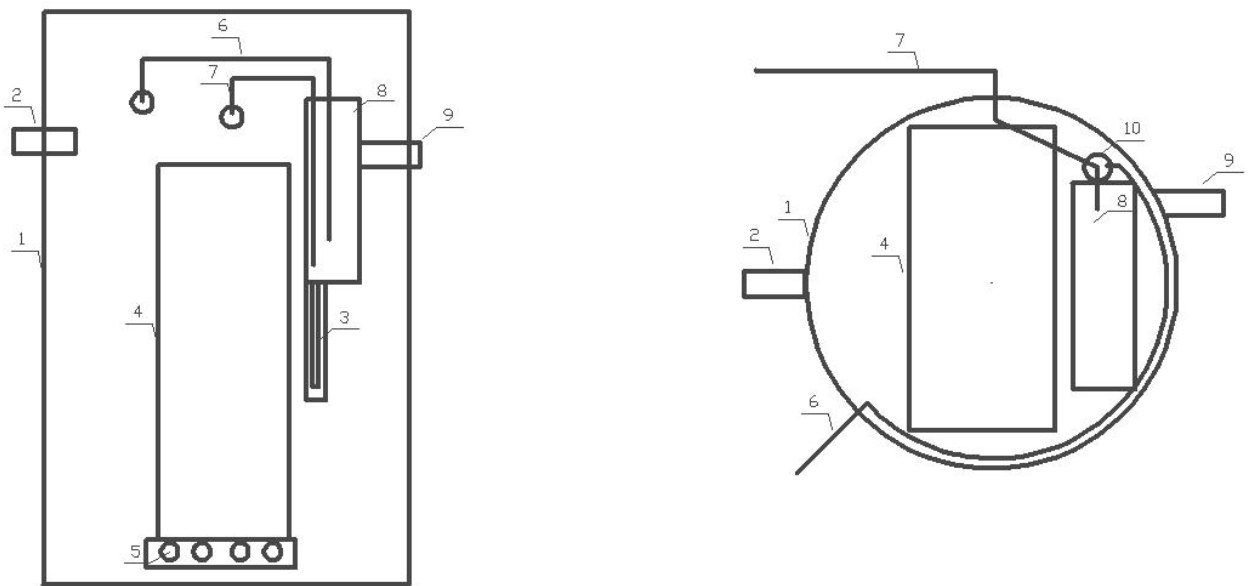

Fig. 3. A scheme of the biological plant with a submerged biofilter (1 - reactor casing, 2 - inlet, 3 - air-lift for wastewater, 4 - biofilter, 5 - grate, 6 - air inlet, 7 - recirculation pipe, 8 - clarifier (with outflow filter), 9 - outlet, 10 - air-lift for sludge 
specified in chapter 2. Pollution removal efficiency and standard deviation of the mean were calculated. Furthermore, the relationship between efficiency and technological parameters of the septic tank were determined.

\section{Results}

\section{Traffic intensity}

The primary factor influencing the amount of water used at MSAs, and therefore the amount of generated wastewater, was vehicle traffic volume. As shown in Figure 4, the number of vehicles on the Poznań - Nowy Tomyśl A2 motorway stretch during the study period ranged from 13,500 units per day in the winter months to nearly 18,000 units per day during the summer months. Category I comprised motorbikes and passenger cars except for those caravans and category II - other vehicles.

Variability of traffic volume during a typical day ranged from $2 \%$ of the daily volume at night hours up to $6 \%$ in the late afternoon hours (Fig. 5).

\section{Volume and quality of wastewater}

Sanitary equipment in toilets at the studied MSAs in July 2008 is listed in Table 2. The volumes of water used at the MSAs were determined based on readings of water meters. Mean daily water consumption calculated from monthly readings is shown in Table 2. Monthly peak factors ranged from 1.28 to 1.74 , with the average (for the 8 studied MSAs) $\mathrm{N}_{\mathrm{m}}=1.52$.
Figure 6 shows the amounts of water used in consecutive days. Diurnal peak factors were higher, ranging from 1.46 to 2.68 , on average $\mathrm{N}_{\mathrm{d}}=1.89$.

In order to calculate the peak factor we used a graph of hourly traffic volumes per day (Fig. 5). Assuming that the percentage of toilet use in relation to the number of road users and the number of people per one vehicle are fixed, the factor obtained $\mathrm{N}_{\mathrm{h}}=1.44$.

For the operation of this type of facilities instantaneous outflows from sanitary appliances are also important. The maximum instantaneous flows for individual facilities calculated according to PN-EN 12056-2 ( $\mathrm{K}=1$ was adopted as for public toilets) ranged from 4.00 to $4.95 \mathrm{~L} / \mathrm{s}$. This outflow, lasting for only 10 seconds, releases from 40 to 50 liters of water, which can seriously affect the operation of the septic tank.

The maximum daily flows estimated by the method developed by Seabloom and Sylvester (1972), assuming 30 people using one appliance at peak hours $(12 \%$ share of peak hour daily flow) producing $9 \mathrm{~L}$ of wastewater (this study), ranged from 15.75 to $22.50 \mathrm{~m}^{3} / \mathrm{d}$. The calculated and measured values largely exceed the nominal flows of wastewater for applied treatment plants (Tab. 2). Wastewater treated in the test facilities came exclusively from toilets. Their composition differed significantly from a typical composition of domestic wastewater and it is rather similar to the composition of black wastewater, due to the similar ratio of $\mathrm{COD}$ to $\mathrm{BOD}_{5}$, ranging from 3 to 4 and a similar low $\mathrm{C} / \mathrm{N}$ ratio, ranging from 0.6 to

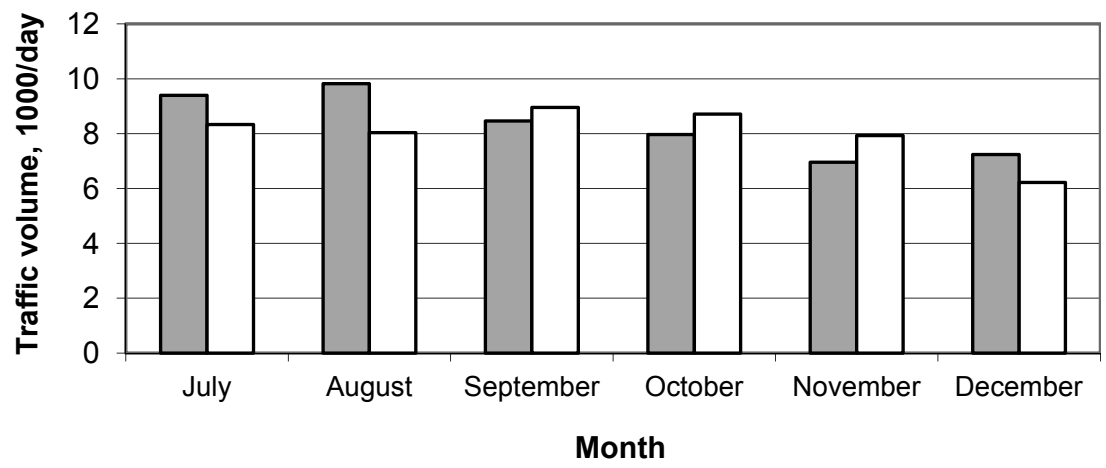

Fig. 4. Average traffic volume between Poznań and Nowy Tomyśl in the second half-year of 2008

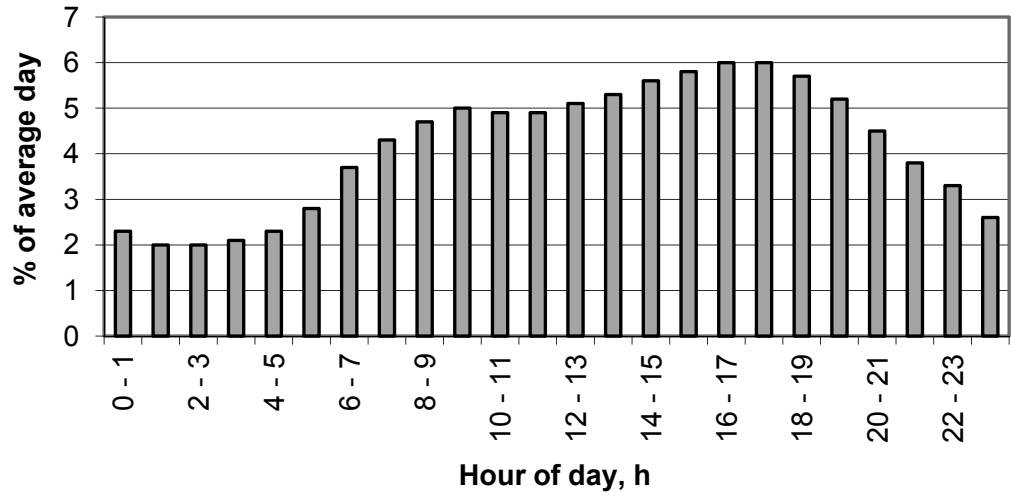

Fig. 5. Hourly traffic variations between Poznań and Nowy Tomyśl within an average day 
3.2. It is also characteristic of the outflow from the septic tank and may affect the efficiency of pollution removal. Pollutant removal efficiencies for the studied systems are shown in Figure 7. As it can be seen, removal efficiency of organic compounds ranged from 39 to $71 \%$ for $\mathrm{BOD}_{5}$ and from 40 to $65 \%$ for COD. The removal efficiency for suspended solids was from 49 to $81 \%$.

The treated wastewater from the tested plants should meet the requirements of the Polish water law for facilities serving up to $2,000 \mathrm{PE}\left(\mathrm{BOD}_{5} \leq 40 \mathrm{mg} \mathrm{O} / \mathrm{dm}^{3}, \mathrm{COD} \leq 150 \mathrm{mgO}_{2} \mathrm{dm}^{3}\right.$ and total suspended solids $\leq 50 \mathrm{mg} / \mathrm{dm}^{3}$ ), except for wastewater treatment plants in Wytomyśl and Kozielaski, where a better effluent quality was required, namely $\mathrm{BOD}_{5} \leq 25 \mathrm{mg} \mathrm{O} / \mathrm{dm}^{3}$, $\mathrm{COD} \leq 125 \mathrm{mg} \mathrm{O}_{2} / \mathrm{dm}^{3}$ and total suspended solids $\leq 35 \mathrm{mg} / \mathrm{dm}^{3}$ ). Nutrient removal was not required.

The average levels of pollutants in the treated wastewater from tested facilities and the percentage exceedance of limit values in purified wastewater are shown in Figures $8 \mathrm{a}, 8 \mathrm{~b}$ and 9. Only a few of the obtained results complied with the above requirements.

The maximum percentage exceedance for limits of $\mathrm{BOD}_{5}$, COD, and suspended solids was respectively $69 \%, 64 \%$ and $54 \%$.
Pollutant loads calculated based on the measured average daily water usage did not appear to exceed the design ones (max. $2 \mathrm{~kg} \mathrm{BOD}_{5} / \mathrm{d}$ ). However, taking into account the maximum hourly flows, the facilities were temporarily overloaded both by organic matter and hydraulically. The observed unreliable performance resulted from the erroneous estimation of the quantity and quality of wastewater in the design process and equipment selection, as well as the design of the systems (an insufficient buffer volume of the septic tank, incorrect design of wastewater effluent clarification, inadequate wastewater flow in the reactor). Treatment efficiency was influenced by the operation and maintenance of the equipment.

\section{Discussion}

This section presents an analysis of the investigated systems and a proposal of structural and technological improvements.

\section{Septic tank}

In the tested on-site wastewater treatment plants septic tanks of $6.7 \mathrm{~m}^{3}$ in volume and the liquid depth in the tank $\mathrm{H}=2.12 \mathrm{~m}$ (from the bottom to the invert of outflow pipe) were installed.

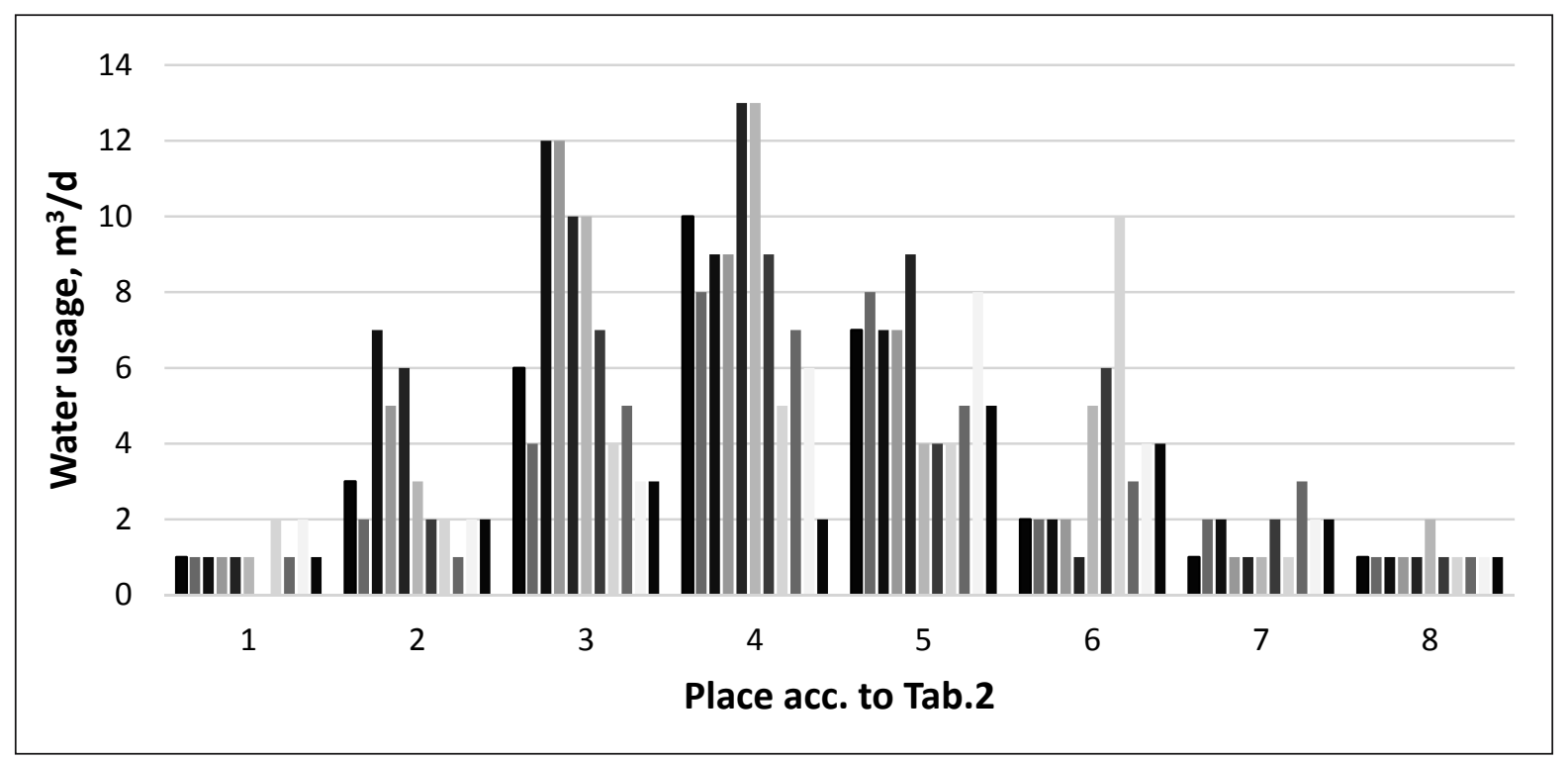

Fig. 6. Water usage in investigated plants in 11 consecutive days of selected weeks

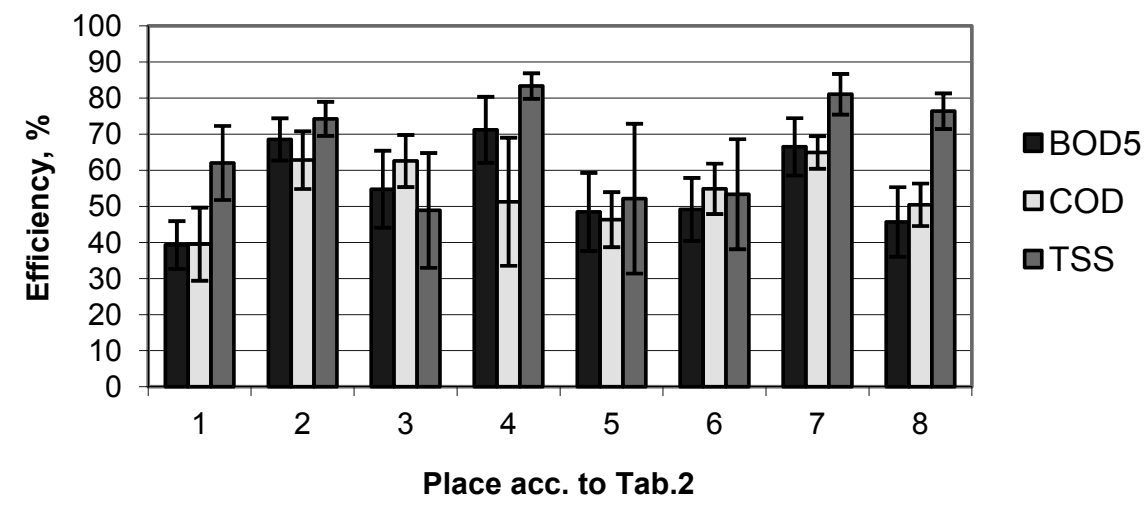

Fig. 7. Mean efficiency of pollutant removal in investigated plants 
a)

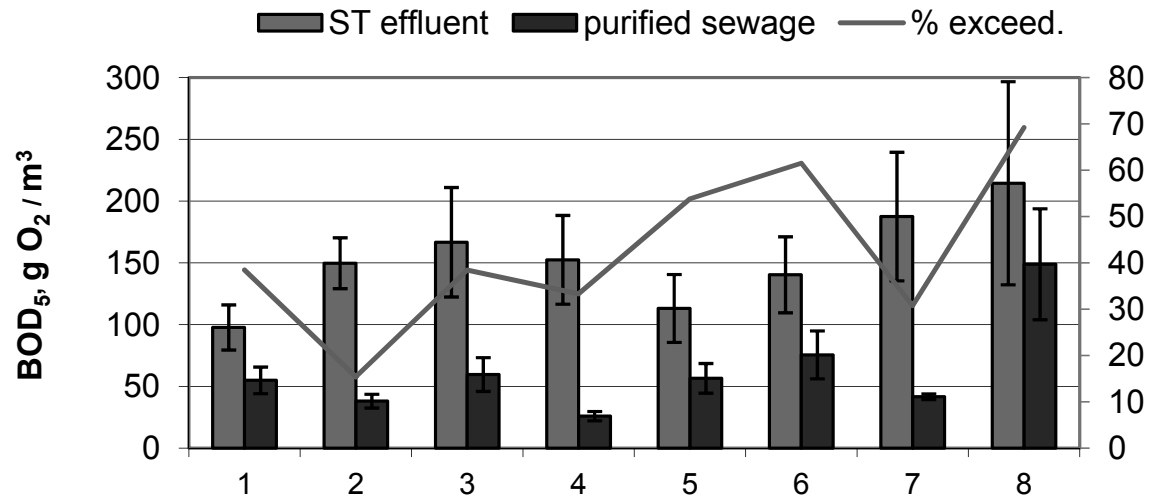

Place acc. to Tab.2

b)

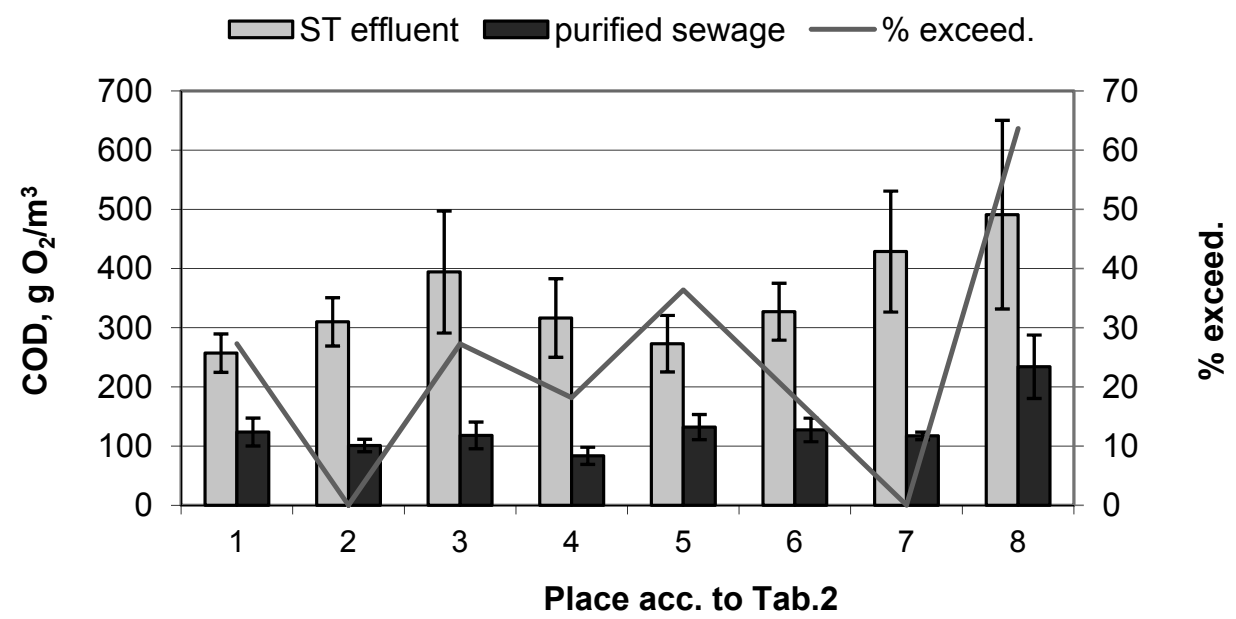

Fig. 8. Mean content of organic compounds in biologically purified wastewater as a) $B O D_{5}$, b) $C O D$

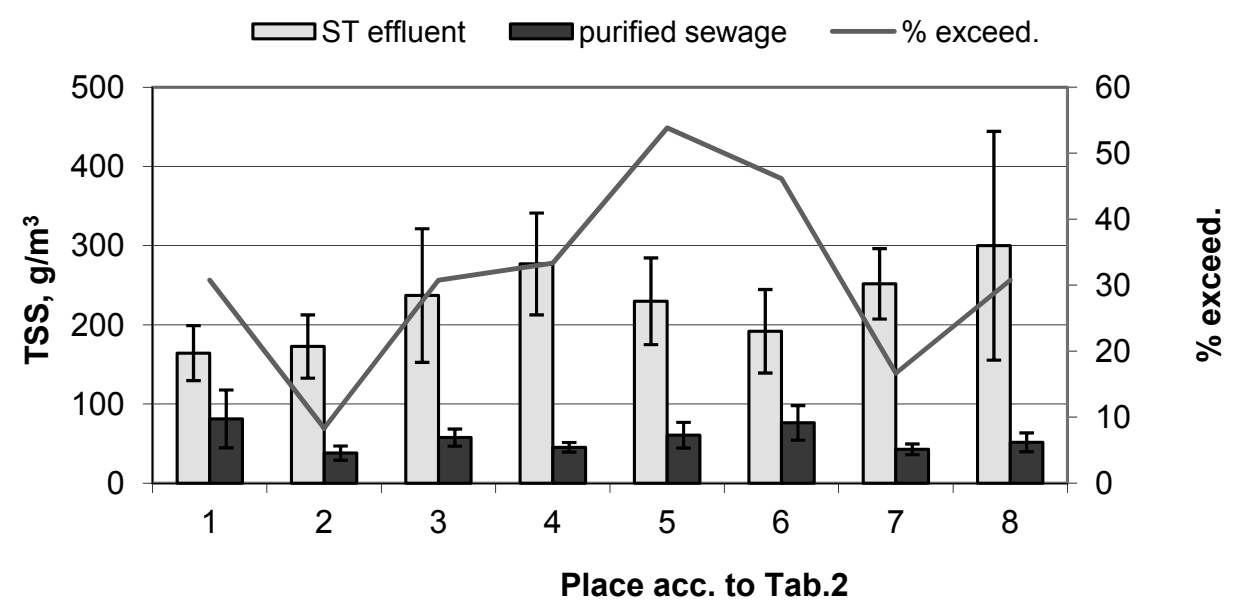

Fig. 9. Mean concentrations of total suspended solids in raw and purified wastewater

According to recommendations by Błażejewski (2003), if the maximum depth of the sludge zone is $0.5 \mathrm{H}$ and the maximum depth of scum is $0.4 \mathrm{H}$, then the minimum volume of the clarification zone in the studied tanks would only be $0.21 \mathrm{~m}^{3}$.

According to the measured average amount of water used (Tab. 2) and the previously calculated daily peak factors, the obtained volume of the clarification zone should be between $3.76 \mathrm{~m}^{3}$ at Gołuski to $16.31 \mathrm{~m}^{3}$ at Kozielaski. The required volume of the flow zone in the septic tank is here so much greater than the actual clarification zone, and even - in five cases - than the total capacity of the settling chamber.

Therefore, not only sediment has no time to settle during the wastewater flow through the settler, but it is also washed 
out with a blanket to the biological reactor. It is irrelevant to have any compartment between the settler chambers and the frequent removal of settler scum. The problem may be connected with the quantity of sludge and scum accumulating in the septic tank.

Assuming that a single use of a toilet produces on average $23 \mathrm{~g}$ of dry mater of suspended solids (Londong and Meyer 2010) and assuming a $6 \%$ content of dry matter in the sludge one can calculate the filling time at the maximum efficiency of solids removal to be only 32 days on condition that the number of users at that time does not exceed 16,000 people. In practice, sludge is removed at every three months. It does not keep the maximum depth of the sludge zone at $0.5 \mathrm{H}$, at which the sediment sludge should be removed.

In order to determine the efficiency of the septic tank (ST) the following relationship was formulated. It includes a volume of ST allocated to sludge and scum storage $(90 \%$ usable volume) and the amount of sludge fed during the period between empting of ST, depending on the number of users of sanitary appliances. In this way the equation was obtained:

$$
\eta_{S T}=\frac{0,9 \cdot V_{S T} \cdot c_{m}}{t_{n} \cdot \overline{L U} \cdot m_{j}}
$$

where:

$V_{S T}$ - active volume of the septic tank, $\mathrm{m}^{3}$,

$c_{m}$ - concentration of sludge and scum, $\mathrm{g} / \mathrm{m}^{3}$,

$t_{n}$ - time between successive emptyings of settler, months,

$\overline{L U}$ - the average number of users per month,

$m_{j} \quad$ - average unit quantity of suspended solids in the settling tank, g/PE

The average number of users per month can be calculated as an arithmetic mean:

$$
\overline{\mathrm{LU}}=\frac{1}{\mathrm{n}} \sum_{\mathrm{i}=1}^{\mathrm{n}} \mathrm{LU}_{\mathrm{i}}
$$

where:

$\mathrm{n}-$ number of months between successive emptyings of the settling tank, $L U_{i}$-number of users in the $i$-th month.

$$
m_{j}=\frac{1}{N} \sum_{j=1}^{N} m_{N j}
$$

If we consider the decay of suspended sludge accumulated in the settler, then its unit quantity $\mathrm{m}_{\mathrm{Nj}}$ after time $t_{N}$ may be expressed using the following relation:

$$
m_{N j}=m_{0} \cdot e^{-K_{d} \cdot t_{N}}
$$

where:

$\mathrm{N}$ - the next day of settler operation,

$m_{0}$ - unit mass of biodegradable suspended solids in raw wastewater, settled in the ST, $\mathrm{g} / \mathrm{PE}$,

$K_{d}$ - decay rate coefficient, $\mathrm{K}_{\mathrm{d}}=\mathrm{f}(\mathrm{T}), \mathrm{d}^{-1}$,

$\mathrm{T}$ - temperature, ${ }^{\circ} \mathrm{C}$.

Zhykov and Yampolskij (1951) determined, that for $\mathrm{T}=18^{\circ} \mathrm{C}-\mathrm{K}_{\mathrm{d}}=0,01$, for $\mathrm{T}=13^{\circ} \mathrm{C}-\mathrm{K}_{\mathrm{d}}=0.005$.

These relationships are important for $t n^{3} 1$ month.

Equation (1) is shown graphically in Figures 10 and 11 for a constant volume of the settler of $6.7 \mathrm{~m}^{3}$ (Fig. 10), and for a fixed number of users of 50,000 (Fig. 11). Analysis of the graphs indicates that with more users and a low frequency of sludge removal the estimated device efficiency decreases significantly (Fig. 10). In turn, assuming a constant number of users, in order to achieve a greater efficiency of the septic tank one has to significantly increase its volume (Fig. 11).

To support treatment processes and reduce the amount of sludge and scum, from July 2008 bioadditives were dosed once a week to the septic tank. As a result of these operations the amount of foam splashed to the biological reactor decreased. Nevertheless, the clarification zone should be enlarged, e.g. by combining it in series with the existing one. Such use of high-capacity septic tanks is recommended by Jowett et al. (2008). More about the proper design and operation designing of septic tanks can be found in studies by Spychała et al. (2013) or Nasr and Mikhaeil (2013), and with aid of computer tools in a paper by Pawlak and Błażejewski (2010). An unusual approach to this type of equipment can be found in a study by Ting et al. (2013). This work presents a novel effluent removal management tool for septic sludge treatment plants using a clonal selection algorithm, which model was simulated using MATLAB.

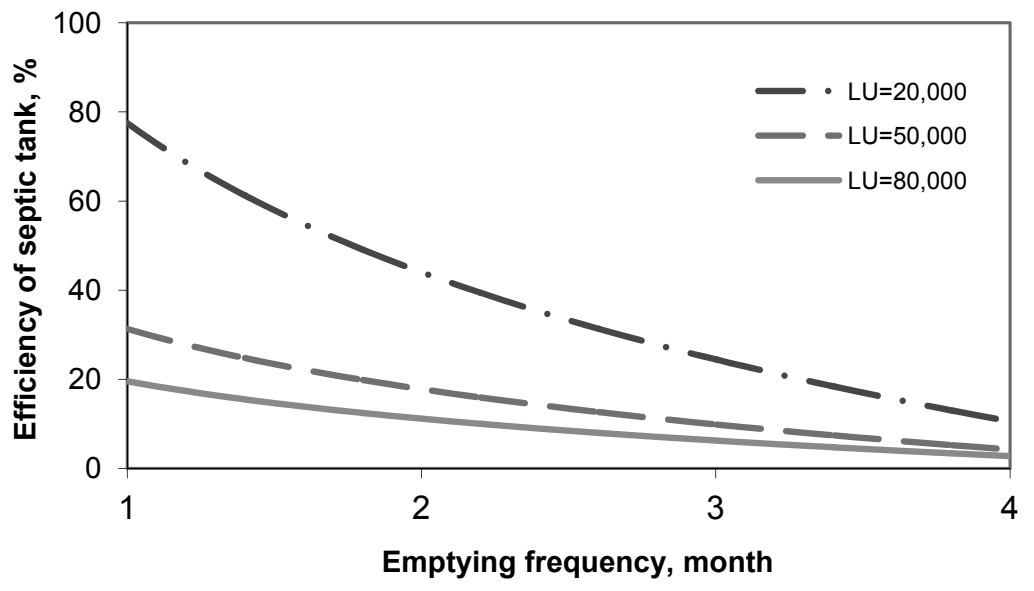

Fig. 10. Efficiency of the septic tank in relation to the number of users and emptying frequency 


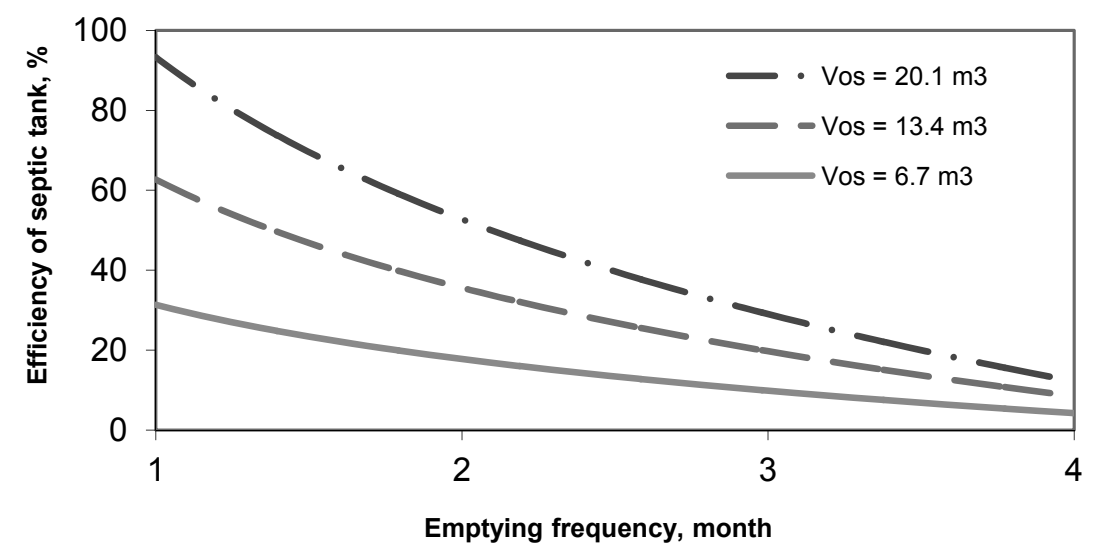

Fig. 11. Efficiency of the septic tank in relation to its emptying frequency

\section{Bioreactor}

A submerged aerated biofilter was installed on the bottom of each bioreactor. Apart from the biomass attached to the biofilter, a comparable amount of biomass in the suspended form was observed in the reactor space. Suspended biomass concentration in the reactor ranged from 0.14 to 0.9 of $\mathrm{mg} / \mathrm{L}$ and sedimentation tests of activated sludge showed results from 10 to $130 \mathrm{~cm}^{3} / \mathrm{L}$ (30 $\mathrm{min}$ ) and the sludge volume index from 200 to $900 \mathrm{~cm}^{3} / \mathrm{g}$. It was therefore necessary to turn the sludge recirculation from the bioreactor into the septic tank to remove excessive sludge if needed.

Aeration of wastewater plays a crucial role in the process of removing organic compounds. Assuming that every $1 \mathrm{~kg}$ $\mathrm{BOD}_{5}$ organic load requires $2 \mathrm{~kg}$ of oxygen and that fine bubble aeration provides only $7 \%$ oxygen from the air delivered at $1 \mathrm{~m}$ immersion of the diffuser (Błażejewski 2003) and the mass of oxygen in the air is $0.276 \mathrm{~kg} / \mathrm{m}^{3}$, then the necessary amount of air and blower operating time at a capacity of $200 \mathrm{~L} / \mathrm{min}$ per diffuser was calculated (by immersing the diffuser to $1.8 \mathrm{~m}$ ). It was only found at one plant in Kozielaski for the required continuous aeration, while the others might be operated more economically - from about 200 to $850 \mathrm{~min} / \mathrm{d}$. Calculation results for all the analyzed plants are shown in tab. 3 .

After a detailed analysis of bioreactor operation it was found that wastewater was flowing in an improper way through the submerged bed, partially bypassing the structured packing. To avoid such "short circuits" it was proposed to insert two partitions made of plastic or other moisture-resistant material. Such a design would facilitate a longer contact of wastewater with air and microorganisms fixed to the submerged bed, and therefore increase the efficiency of wastewater treatment and eliminate the direct supply of sludge to the outlet. It seems that the quality of effluent could be improved also in the constructed wetlands as the tertiary treatment step. Such solutions have been successfully used at MSAs in Germany (Londong and Meyer 2010).

\section{Clarification chamber}

Based on the analysis of treatment plant operation it was found that the clarification chamber located at the outlet of a biological reactor did not serve its role. A multistream package did not provide sedimentation of sludge. Additionally, bubbling (aeration) often took place during inflow of wastewater into the bioreactor, which resulted in an additional washout of suspension into the outflow. An insufficient air-lift capacity also did not provide an adequate removal of washings.

The unsatisfactory sedimentation properties of sludge (Mohlman index above 200) strengthened the adverse effect of wastewater clarifying. It is therefore proposed to replace the outflow of the sludge recirculation pipe to the inflow into the bioreactor (element 7 in fig. 3), flushing the filter outflow 4 times a day (including once at night) with a simultaneous removal of backwash to the septic tank. To increase the efficiency of the airlift the air redistribution was proposed. A good solution might be to instal a pocket settler in place of the outflow filter (element 8 in fig.3) and remove excess biomass from the reactor bottom.

\section{Conclusions}

On the basis of the analysis it was found that:

1. The composition of wastewater from highway rest areas differs significantly from the average composition of municipal wastewater .

2. Septic tanks used as part of pre-treatment have too small clarification zones in relation to the daily flows of wastewater, as a consequence scum and sludge from these zones flowed into the bioreactor chamber.

3. An improper design of the studied bioreactor with a submerged bed (lateral "short circuits") did not ensure an appropriate time of contact between wastewater, air and microorganisms; moreover, the hydraulically overloaded outflow filter did not effectively settle suspended solids from the effluent.

4. The bioreactor should be operated as a hybrid system with the removal of excess suspended biomass to the septic tank.

5. Intermittent aeration of the bioreactor is recommended to diminish energy costs, enhance denitrification and straining by the outflow filter.

6. Mechanical-biological systems may be used to treat wastewater from highway rest areas, but they must be designed with particular reference to variations in the quantity and quality of raw wastewater.

\section{Acknowledgement}

The authors wish to sincerely thank Prof. Ryszard Błażejewski from the University of Live Sciences in Poznań for his valuable comments during research by Piotr Olszak, M. Sc., and Paweł 
Table 3. The amount of air volume and blower operating times in investigated wastewater treatment plants

\begin{tabular}{|c|c|c|c|c|c|}
\hline No. & Place & $\begin{array}{c}\text { Average load } \mathrm{BZT}_{5}, \\
\mathrm{kgO}_{2} / \mathrm{d}\end{array}$ & $\begin{array}{c}\text { Calculated oxygen emand, } \\
\mathrm{kgO}_{2} / \mathrm{d}\end{array}$ & $\begin{array}{c}\text { Calculated air emand, } \\
\mathrm{m}^{3} / \mathrm{d}\end{array}$ & $\begin{array}{c}\text { Blower time, } \\
\mathrm{min} / \mathrm{d}\end{array}$ \\
\hline 1 & Gołuski Płn. & 0,6 & 1,2 & 35 & 173 \\
\hline 2 & Dopiewiec & 1,0 & 2,0 & 58 & 288 \\
\hline 3 & Sędzinko & 1,1 & 2,2 & 63 & 316 \\
\hline 4 & Wytomyśl & 2,8 & 5,6 & 276 & 1605 \\
\hline 5 & Kozielaski & 4,8 & 9,6 & 150 & 7380 \\
\hline 6 & Zalesie & 2,6 & 5,2 & 121 & 748 \\
\hline 7 & Konarzewo & 2,1 & 4,2 & 52 & 604 \\
\hline 8 & Gołuski Płd. & 0,9 & 1,8 & & 259 \\
\hline
\end{tabular}

Wojciechowski, Eng., from WODKAN S.A. for their financial support in this field of research.

\section{References}

Błażejewski, R. (2003). Rural sanitation, PZITS Poznań (2003). (in Polish)

Expertise on environmental protection concerning renewal of National Development Strategy 2007-2015, (2010) CDM Warszawa. (in Polish)

Helman-Grubba, M., Marcinkowski, M. \& Falkowski, W. (2004), Effective protection of the surrounding roads - theory and practice, International Scientific - Technical Conference on the Protection of surface and ground waters and soils along roads and highways. (in Polish)

Jowett, C., Payette, C., Harsch, D., Sommer, M. \& Defoort, D. (2008), Re-using truck stop sewage for toilets and truck washing, WAFTEC Tech. Prog. 76, Chicago.

Kiss, A., Hai, F.I. \& Ngheim, L.D. (2011), Roadside rest area wastewater treatment system: Performance evaluation and improvement, Desalination and Water Treatment, , 32, pp. 389-396.

Leverenz, H. \& Tchobanoglous, G. (2007). Identification of research needs for effective low cost wastewater treatment technologies, Proc. WEF, WEFTEC.

Londong, J. \& Meyer, D. (2010). Abwasserbehandlung an PWC - Anlagen, Bauhaus Universitaet Weimar, Weimar 2010.

Nasr, F.A. \& Mikhaeil, B. (2013). Treatment of domestic wastewater using conventional and baffled septic tanks, Environmental Technology, 34, pp. 2337-2343.
Parker, C.E., Ritz, M.A., Heitman, R.H. \& Kitchen, J.D. (1977). Geometrics, water treatment, utility practices, safety appurtenances, and outdoor advertisement, Transportation Research Record, 631, Washington, USA 1977.

Pawlak, M. \& Błażejewski, R. (2010). Mathematical model of sedimentation and flotation in a septic tank, in: Environmental Engineering III, L. Pawłowski, M.R., Dudzińska \& Pawłowski, A. (Eds.)., CRS Press, Taylor \& Francis Group 2010.

Pearson, F., Grottkau, W.A. \& Jenkins, D. (1984). Wastewater Treatment and Hydraulics, Transportation Research Record, 995, Washington 1984.

Seabloom, R. \& Sylvester, R.O. (1972). Rest area wastewater disposal, Departament of Civil Engineering, University of Washington. Seattle, Washington 1972.

Song, F., Tian, W. \& Zhao, Q. (2011). Sewage Treatment Choice of Ancillary Facility of Si-Xiao Expressway, Shandong University of Science and Technology, Qingdao, China 2011. (http:// en.cnki.com.cn/Article en/CJFDTOTAL-GLGL200508037.htm (08.09.2016)).

Spychała, M., Nieć, J. \& Pawlak, M. (2013). Preliminary study on filamentous particle distribution in septic tank effluent and their impact on filter cake development, Environmental Technology, 34, pp. 2825-2833.

Tinga, S.C., Ismailb, A.R. \& Maleka, M.A. (2013). Development of effluent removal prediction model efficiency in septic sludge treatment plant through clonal selection algorithm, Journal of Environmental Management, 29, pp. 260-265.

Zhukov, A.J. \& Yampolskij, T.S. (1951). Underground seepage of wastewater. GISL, Moskwa 1951.

\section{Oczyszczanie ścieków z miejsc obsługi podróżnych przy autostradzie}

Streszczenie: Praca dotyczy systemów oczyszczania ścieków w Miejscach Obsługi Podróżnych (MOP) przy autostradach. Badano i analizowano 8 instalacji zamontowanych w MOP-ach przy autostradzie A2 między Poznaniem a Nowym Tomyślem. Systemy składają się z osadnika gnilnego, zanurzonego, napowietrzanego złoża biologicznego i filtra odpływowego. Analizowano natężenie ruchu na autostradzie, ilość zużywanej wody oraz jakość ścieków na wlocie i wylocie z bioreaktora. Na tej podstawie stwierdzono, że wielkość oczyszczalnie nie jest adekwatna do ilości i jakości dopływających ścieków. Stwierdzono, że jakość odpływu jest niezadowalająca oraz zaproponowano zmiany konstrukcyjne i technologiczne. 